\title{
The Nexus between Economic Growth and Public Spending in Eastern European Countries
}

\author{
Dan Lupu, Mircea Asandului
}

\author{
Alexandru Ioan Cuza University of Iasi \\ Carol I no.22, Iasi, 700505, Romania \\ E-mail.danlupu20052000@yahoo.com,asmircea@yahoo.com
}

cross $^{\text {ref }}$ http://dx.doi.org/10.5755/j01.ee.28.2.7734

\begin{abstract}
This study analyses the relationship between governmental expenditure and economic growth rate for 8 Eastern-European countries with data for 1995-2014 using the ARDL model. The main goal of the present study is to test the presence of a non-linear - Armey Curve type - relationship between the government size and economic growth and also to find an optimal level of public spending which maximizes economic growth. Our results reveal the occurrence of a significant cointegration of public spending and economic growth for all considered countries and show that the current share of public spending within the Gross Domestic Product (GDP) exceeds the optimal level calculated for the three countries for which the Armey-type phenomenon occurs. Also, the results suggest that the optimal percentage of governmental spending varies between $37 \%$ and $41 \%$ and the present level is higher than the optimal level for Bulgaria, Hungary and Romania. The outstripping of the optimal level may conclude to the idea that the weight of public sector should be slightly decreased in these countries since the public sector is not able to efficiently cope with its resources. Based on the study results, the weight of public expenditure should be reduced while the efficiency of public spending programs should be increased.
\end{abstract}

Keywords: Public Expenditure; Economic Growth; Eastern European Countries; ARDL Model; Armey Curve.

\section{Introduction}

The importance of the efficient use of public resources for economic growth has been brought to the forefront by a number of studies over the past decades. The debate regarding the impact of government spending on economic growth during the last 60 years are focused on positive and negative effects (Hansson \& Henrekson, 1994; Deacon, 2000; Mencinger \& Aristovnik, 2013).

The neoclassical growth literature has long ago emphasized the importance of capital accumulation, labour-force and exogenous technological progress in driving economic growth (Solow, 1956). More recently, endogenous growth theory has made clear that other variables like R\&D investment, institutions, and government spending also have a significant impact economic growth (Acemoglu, 2009; Aghion \& Howitt, 2009; Barro \& Sala-i-Martin, 2004).

Since the pioneering work of Barro (1991) and Barro \& Sala-i-Martin (1992), it is widely acknowledged that government spending can affect economic growth.

During the current global financial crisis, the topic is of outmost importance for emerging and developed countries, especially the United States and European Union that since 2007 were confronted with large decreases in economic growth combined with increasing public debt. During the financial crisis governments chose to support economic growth through expansionist policies based on an significant increase in public spending, thus determine an increase of the budget deficit and public debt (RomeroAvila \& Strauch, 2008). It is a fact that the governmental sector incorporates a relatively important proportion of the national economic resources and, therefore, it affects economic growth (Afonso \& Furceri, 2010; De Witte \& Moesen, 2010).

In order to efficiently use public spending, as a general rule, a functional and transparent market economy is required; its goal is to ensure the Gross Domestic Product (GDP) growth while the uncontrolled expansion of governmental sector cannot necessarily comply with the maximization of the long-term GDP growth rate (Dalamagas, 2000; Gupta et al., 2003). Indeed, if the share of public sector in economy increases, the role and importance of private sector are restricted. Thus, the identification of a balance point between these two components is very important. A higher GDP growth rate in an unbalanced society may not be in accordance with the maximization of its citizens' social welfare (Deacon, 2000; Romero-Avila \& Strauch, 2008).

It is important to know whether there is a point beyond which the increase of public spending reduces the economic growth rate and how the selection of the public policies goals assures the improvement of the public sector quality (Agell et al., 1997; Dar \& Amir Khalkhali, 2002).

The empirical studies based on the endogenous growth models showed that the impact of public spending on economic growth depends on its structure and classified the public expenditure into productive and non-productive (Fölster \& Henrekson, 2001; Forte \& Magazzino, 2011). Thus, the public spending for infrastructure and transport, utilities, education and defence are often cited as a typical example of governmental expenditure that can promote long-term economic growth (Kalaitzidakis \& Kalyvitis, 2005). Moreover, apart from these typical examples of 
expenditure that can be considered stimuli of economic growth, there are other categories of public spending that support indirectly the economic growth ( e.g. spending for social order, social security, health) (Colombier, 2011; Sineviciene \& Vasiliauskaite, 2012). Therefore, there is a series of public expenditure that, directly or indirectly, using the adequate measures and during right moments, positively contribute to the creation of the gross domestic product and national wealth, promoting economic growth. This implies that the structure of public spending may be more relevant than its level (Shelton, 2007).

The aim of this study is to investigate, at the level of Eastern European countries, the relationship between public expenditure and economic growth. The distinct feature of this study implies testing the existence of the optimal public spending, postulated by the Armey Law, for a number of 8 ex-communist countries that are now members of the European Union.

The choice of this group of states has been taken based on their mutual communist past and on their present European Union member status that implies an economic harmonization and a common policy in the public life aspects. In order to conduct our analysis, we took into consideration the period 1995-2013 and we used quarterly time series.

Our study is one of the first papers that analyses, in the Eastern European countries, the relationship between public spending and economic growth focusing on the optimum that could maximize economic growth. Previous studies concerning the existence of an Armey law are focused only on the developed countries.

The paper is organized as follows: Section 1 reviews the main literature, both background theory and empirical studies; Section 2 describes the methodology used in our study; Section 3 discusses the empirical results and Section 4 concludes.

\section{Literature Review}

The phenomenon of economic growth has become nowadays one of the most important part of the sustainable development research, becoming a significant factor in the public spending theory starting from the Keynesian model.

Nonetheless, up to now, the topic of the relationship public expenditure-economic growth has not received a clear answer either from the economic theory or from the empirical studies. Traditionally, the theory of market failures has focused on the growth-enhancing effects of the government expenditure, while the theory of government failures has insisted on the negative influence of the state activity on the economic growth. The theoretical debate fostered a vast empirical literature (Karras, 1996; Nijkamp \& Poot, 2004) concerning the effect of government size (defined as the share of public expenditure in the GDP) on economic growth.

The nexus between government spending and economic growth was initially studied using linear models, e.g. Cobb Douglas type function (Feder, 1982; Ram, 1986). Previous studies highlighted significant but ambiguous effects, either positive or negative, that depends on the countries and periods analysed. Facchini \& Melki (2011) showed that in the majority of studies $(73 \%)$ on this relationship the authors test only the linear correlation between these variables, of which $64 \%$ finds a negative effect, $11 \%$ finds a positive effect and $25 \%$ was not conclusive.

Grossman (1987) proposes and proves, for the first time, the existence of a non-linear relationship between the two components, but only to a certain extent. Similarly, the literature underlined the existence of a $\cap$-type curve between the government size and the GDP growth, named the Armey Curve (Armey, 1995), Ram Curve (Ram, 1986) or BARS curve referring to Barro (1990) and Scully (2003). Subsequently, many studies have been developed for different countries and periods (Lin, 1994; Karras, 1996; Kolluri et al., 2000; Afonso et al., 2005; Pevcin, 2004; Forte \& Magazzino, 2011; Facchini \& Melki, 2011).

The Armey Curve reflects the relationship between the importance of public sector in economy (the public expenditure/GDP ratio) and the real GDP (or the real GDP growth rate). It states that there is a positive correlation between public expenditure and GDP until a certain point, after which the correlation becomes negative (Vedder \& Gallaway, 1998). Also, consider that if the public sector would be theoretically non-existent, then the economic growth would be equivalent to zero.

The increase of public spending leads to a GDP growth until a certain point when economic growth reaches its maximum value, the maximal productivity of public spending is equal to the marginal productivity of public sector spending and the economic contribution of public spending is zero. After this point, the additional increase of public spending will determine stagnation or even economic contraction.

\section{Methodology}

The following mathematical model may illustrate the empirical tests regarding the existence of the Armey Curve:

$$
\text { GDPgrowth }=f(\operatorname{Exp}, N)
$$

where GDP growth measures the Real GDP growth rate, Exp indicates the state intervention in economy (public expenditures), while $N$ represents the existence of certain exogenous factors.

The non-linear regression specification which should be estimated has the following form:

$$
\text { GDPgrowth }_{t}=\alpha_{0}+\alpha_{1} \operatorname{Exp}_{t}+\alpha_{2} \operatorname{Exp}_{t}^{2}+\varepsilon_{t}
$$

where $\varepsilon_{t}$ are the residuals and $\alpha_{i}$ are the estimated coefficients with the expected condition that $\alpha_{2}<0$.

If the public spending coefficient $\left(\alpha_{1}\right)$ has a positive sign in this function, this has a positive impact on the GDP; likewise, if the coefficient of the square function of public spending $\left(\alpha_{2}\right)$ is negative in the previous function then the negative consequences of an oversized state occur.

In order to perform an as stable econometric model as possible and to notice the effects of business cycles, we introduced in the previous equation a control variable, namely unemployment.

The unemployment $(U)$ variable is expected to have a negative sign because the unemployment increase leads to economic growth drop and vice versa. In this scenario, equation (2) will be extended as follows: 
GDProwth $_{t}=\alpha_{0}+\alpha_{1} \operatorname{Exp}_{t}+\alpha_{2} \operatorname{Exp}_{t}^{2}+\alpha_{3} U_{t}+\varepsilon_{t}(3)$

where $\varepsilon_{t}$ are the residuals and $\alpha_{i}$ are the estimated coefficients with the imposed conditions that $\alpha_{2}<0$ and $\alpha_{3}<0$.

When analyzing equation (3) as a 2-order function that needs to be maximized, we can determine the extreme point of the function, therefore the optimal level of public spending as a percentage of the GDP. We will derivate the function (3) in relation to the variable $\operatorname{Exp}$ and the result will be equalized with zero, giving thus the following equation:

$$
2 \alpha_{2} \operatorname{Exp}+\alpha_{1}=0
$$

The optimal level of public spending that will maximize economic growth will be equal to:

$$
\operatorname{Exp}=-\frac{\alpha_{1}}{2 \alpha_{2}}
$$

If we are in the case when some of the considered series are stationary $(\mathrm{I}(0))$ and some are stationary by doing the first difference level $(\mathrm{I}(1))$, the traditional cointegration Johansen test cannot be applied. This problem can be solved by using the Autoregressive Lag Distributed (ARDL) model, developed by Pesaran et al. (2001) through the observation of the long-term relationship between variables. The cointegration method used in this study, ARDL, allows testing the long-run relationship between variables which have a different integration order. Taking into account the previous equations, the model can be written as:

$$
\begin{aligned}
& \Delta \text { GDPgrowth }_{t}=\beta_{0}+\beta_{1} \Delta \text { GDP } \text { growth }_{t-1}+\beta_{2} \Delta \operatorname{Exp}_{t-1} \\
& +\beta_{3} \Delta \operatorname{Exp}_{t-1}{ }^{2}+\beta_{4} \Delta U_{t-1}+\beta_{5} \text { GDPgrowth }_{t-1}+ \\
& \beta_{6} \operatorname{Exp}_{t-1}+\beta_{7} \operatorname{Exp}_{t-1}^{2}+\beta_{8} U_{t-1}+\varepsilon_{t}
\end{aligned}
$$

where $\Delta$ denotes the first difference operator, $\beta_{i}$ are the estimated coefficients and $\varepsilon_{t}$ represents the residuals.

In order to establish the accuracy of the ARDL model, diagnosis tests are performed (series correlation, normality and heteroscedasticity associated with the model) as well as stability tests (sum of cumulative residues and cumulative sum of recursive residual squares). For the cointegration relation in equation 6 we test the methodology formulated by Pesaran et al. (2001) for the ARDL model: the null hypothesis of no-cointegration will be rejected if the calculated F-statistics is higher than the superior threshold of the critical value or is lower than the inferior threshold of the critical value; in case that the calculated F-statistics is between inferior and superior thresholds, then the null hypothesis of no-cointegration is admitted. In this study, the maximum lag length was 4 considering the quarterly data.

Considering that the period analysed in our study contains the global financial crisis started in 2007, we used Zivot-Andrews Unit Root Test in order to identify the time series structural. Zivot and Andrews (1992) offer methods of determination of structural breaks in a time series at an unknown moment through the development of 3 models: i) model A allows for an exogenous change of the series level, enabling the level variation within the series level; ii) model $\mathrm{B}$ allows an exogenous change of the growth rate through the level variation in the function slope; and iii) model $\mathrm{C}$ admits two modifications, combining changes of level and the trend function slope of the series.
For testing the structural breaks we assume that the tested series $\left(y_{t}\right)$ follows an autoregressive process. The specifications of these three models are the following:

Model with Intercept (Model A)

$$
\Delta y_{t}=\delta_{0}+\delta_{1} y_{t-1}+\delta_{2} t+\delta_{3} D U_{t}+\sum_{j=1}^{k} d_{j} \Delta y_{t-j}+\varepsilon_{t} \text { (7) }
$$

Model with Trend (Model B)

$$
\Delta y_{t}=\delta_{0}+\delta_{1} y_{t-1}+\delta_{2} t+\delta_{4} D T_{t}+\sum_{j=1}^{k} d_{j} \Delta y_{t-j}+\varepsilon_{t}
$$

Model with Intercept and Trend (Model C)

$$
\begin{aligned}
& \Delta y_{t}=\delta_{0}+\delta_{1} y_{t-1}+\delta_{2} t+\delta_{3} D U_{t}+\delta_{4} D T_{t} \\
& +\sum_{j=1}^{k} d_{j} \Delta y_{t-j}+\varepsilon_{t}
\end{aligned}
$$

where:

- $\Delta$ denotes the first difference operator;

- $D U_{t}$ indicates a mean shift occurings at each possibile structural break (TB); $D U_{t}=1$ if $t>T B, 0$ in the opposite case;

- $D T_{t}$ indicates a trend shift; $D T_{t=t-T B}$ if $t>T B$ and 0 in the opposite case;

- $\delta_{i}$ and $d_{j}$ are the estimated coefficients;

$-\varepsilon_{t}$ are the residuals.

If the minimum computational value of F-statistics for each model is higher than the critical value, the null hypothesis will be rejected in favour of the alternative hypothesis; the null hypothesis states that the unit root exists without any structurally exogenous break, while the alternative hypothesis implies the stationary status of the series in the presence of a structural break during an unknown time period (Zivot \& Andrews, 1992; Chen \& Lee, 2005).

\section{Empirical Results}

In this study, we used data sets obtained from the quarterly reports of the national Institutes of Statistics and Eurostat for 8 Eastern-European countries, namely Bulgaria, Czech Republic, Estonia, Hungary, Latvia, Lithuania, Poland and Romania. In our analysis we used the values of public spending, economic growth and unemployment for 1995Q1-2013Q4 period. Public spending $(\operatorname{Exp})$ is expressed as percentage values in the GDP, economic growth is measured using Real GDP growth rate (GDPgrowth) and the unemployment $(U)$ is measured according to the Eurostat regulations, calculated as a percentage of the labour force. Table 1 presents the descriptive statistics for the variables used in our study.

From Table 1, we can notice that the average public spending for the selected countries range between $37.09 \%$ and $49.98 \%$, with Hungary that recorded the highest value. During the pre-crisis period, all Eastern European countries have recorded very high levels of the public spending (range between $50 \%$ and $60 \%$ ), but subsequently dropped at the present values. The average level of economic growth for these countries has known modest values ranged between $1.5 \%$ and $3.34 \%$, the leader being Romania. During economic boom periods, the Eastern European countries have experienced very high levels of GDP growth, with a maximum of $25.3 \%$ 
(Romania). Still, during the crisis period the GDP drops have been equally impressive as the previous growths. Regarding the unemployment rate, the country average values ranges between $6.87 \%$ (Romania) and $13.53 \%$ (Poland).

Descriptive Statistics

Table 1

\begin{tabular}{|c|c|c|c|c|c|c|c|c|c|c|c|c|}
\hline & \multicolumn{3}{|c|}{ Bulgaria } & \multicolumn{3}{|c|}{ Czech Republic } & \multicolumn{3}{|c|}{ Estonia } & \multicolumn{3}{|c|}{ Hungary } \\
\hline & $\operatorname{Exp}$ & GDPgrowth & $U$ & Exp & GDPgrowth & $U$ & $\operatorname{Exp}$ & GDPgrowth & $\bar{U}$ & $\operatorname{Exp}$ & GDPgrowth & $\bar{U}$ \\
\hline Mean & 38.54 & 2.11 & 12.53 & 43.47 & 1.90 & 7.26 & 37.09 & 2.251 & 10.54 & 49.83 & 1.51 & 7.94 \\
\hline Maximum & 56.98 & 5.69 & 20.00 & 60.91 & 13.59 & 9.30 & 47.81 & 6.48 & 18.50 & 61.42 & 11.38 & 11.40 \\
\hline Minimum & 28.68 & -4.87 & 5.00 & 37.02 & -17.44 & 4.20 & 30.44 & -6.03 & 4.00 & 43.35 & -12.55 & 5.50 \\
\hline \multirow[t]{2}{*}{ Std. Dev. } & 5.77 & 2.15 & 4.69 & 3.92 & 5.32 & 1.26 & 4.19 & 2.36 & 3.57 & 3.75 & 3.71 & 2.07 \\
\hline & & Latvia & & & Lithuania & & & Poland & & & Romania & \\
\hline Mean & 37.67 & 2.31 & 12.44 & 37.12 & 2.29 & 12.20 & 43.33 & 2.53 & 13.53 & 37.51 & 3.34 & 6.87 \\
\hline Maximum & 51.27 & 10.85 & 20.80 & 50.35 & 10.27 & 18.40 & 48.12 & 18.49 & 20.40 & 52.03 & 25.09 & 8.30 \\
\hline Minimum & 30.51 & -7.88 & 5.60 & 29.62 & -12.04 & 4.10 & 37.62 & -25.28 & 6.80 & 28.95 & -36.76 & 5.30 \\
\hline Std. Dev. & 4.73 & 3.64 & 3.79 & 5.09 & 3.45 & 4.31 & 1.85 & 9.96 & 4.54 & 5.32 & 8.43 & 0.69 \\
\hline
\end{tabular}

Source: own calculations

We begin our analysis by identifying the structural breaks; this has been done using the Zivot-Andrews test for each of the three series, separately for each country. The test results are presented in Table 2. We notice that, as it was expected and according to the economic phenomena, the structural breaks are present during the analyzed period. These break points are almost similar for all time series; the only notable exception is Poland that does not present a structural break during this period, being the only country of the sample that has not been affected by the economic

crisis.

Zivot-Andrews Unit Root Test

Table 2

\begin{tabular}{|c|c|c|c|c|c|c|c|c|}
\hline & Coefficient & Period & Coefficient & Period & Coefficient & Period & Coefficient & Period \\
\hline & \multicolumn{2}{|c|}{ Bulgaria } & \multicolumn{2}{|c|}{ Czech Republic } & \multicolumn{2}{|c|}{ Estonia } & \multicolumn{2}{|c|}{ Hungary } \\
\hline $\operatorname{Exp}$ & -4.1802 & 2007Q4 & -4.9925 & 2004Q1 & -6.5083 & 2008Q1 & -5.6940 & $2002 \mathrm{Q} 2$ \\
\hline GDPgrowth & -4.8832 & 2008Q4 & -5.4637 & 2008Q4 & -7.0452 & 2008Q3 & -7.4348 & 2008Q4 \\
\hline \multirow[t]{2}{*}{$U$} & -4.9967 & 2006Q4 & -5.3631 & 2006Q2 & -5.8780 & 2008Q3 & -5.8264 & 2009Q1 \\
\hline & \multicolumn{2}{|c|}{ Latvia } & \multicolumn{2}{|c|}{ Lithuania } & \multicolumn{2}{|c|}{ Poland } & \multicolumn{2}{|c|}{ Romania } \\
\hline $\operatorname{Exp}$ & -5.0679 & 2008Q4 & -5.8036 & 2008Q4 & -3.8275 & 2009Q4 & -6.9741 & 2006Q4 \\
\hline$U$ & -7.1657 & 2008Q1 & -6.5932 & 2008Q3 & -4.3366 & 2005Q3 & -5.6163 & 2006Q4 \\
\hline
\end{tabular}

Source: own calculations

After we have identified the structural break points, we test the stationarity of the series used in our analysis. The test used for stationarity is Augmented Dickey-Fuller (ADF) and the results are presented in Table 3. The series containing public spending and unemployment are first order integrated (I(1)), while the series GDP growth are stationary $(\mathrm{I}(0))$.

Augmented Dickey-Fuller Statistical Test

Table 3

\begin{tabular}{|c|c|c|c|c|c|c|c|c|}
\hline & Coefficient & Process & Coefficient & Process & Coefficient & Process & Coefficient & Process \\
\hline & \multicolumn{2}{|c|}{ Bulgaria } & \multicolumn{2}{|c|}{ Czech Republic } & \multicolumn{2}{|c|}{ Estonia } & \multicolumn{2}{|c|}{ Hungary } \\
\hline $\operatorname{Exp}$ & -18.3124 & $\mathrm{I}(1)$ & -7.4284 & $\mathrm{I}(1)$ & -4.4539 & $\mathrm{I}(1)$ & -15.7438 & $\mathrm{I}(1)$ \\
\hline GDPgrowth & -3.2133 & $\mathrm{I}(0)$ & -4.1928 & $\mathrm{I}(0)$ & -5.3507 & $\mathrm{I}(0)$ & -5.6480 & $\mathrm{I}(0)$ \\
\hline \multirow[t]{2}{*}{$U$} & -3.5698 & $\mathrm{I}(1)$ & -4.2360 & $\mathrm{I}(1)$ & -4.1461 & $\mathrm{I}(1)$ & -3.8839 & $\mathrm{I}(1)$ \\
\hline & \multicolumn{2}{|c|}{ Latvia } & \multicolumn{2}{|c|}{ Lithuania } & \multicolumn{2}{|c|}{ Poland } & \multicolumn{2}{|c|}{ Romania } \\
\hline $\operatorname{Exp}$ & -13.6722 & $\mathrm{I}(1)$ & -3.8880 & $\mathrm{I}(1)$ & -3.7150 & $\mathrm{I}(1)$ & -14.7610 & $\mathrm{I}(1)$ \\
\hline GDPgrowth & -3.8145 & $\mathrm{I}(0)$ & -4.6487 & $\mathrm{I}(0)$ & -4.3927 & $\mathrm{I}(0)$ & -6.5962 & $\mathrm{I}(0)$ \\
\hline$U$ & -4.2798 & $\mathrm{I}(1)$ & -6.0613 & $\mathrm{I}(1)$ & -3.6977 & $\mathrm{I}(1)$ & -3.3688 & $\mathrm{I}(1)$ \\
\hline
\end{tabular}

Source: own calculations

The next steps are to estimate the ARDL model and the F-statistics in order to examine the existence of the cointegration between the analyzed variables in the considered period. The F-statistics results for the ARDL model are reported in Table 4. The critical values of Fstatistics will be those computed by Pesaran et al. (2001) and the results for all the estimated models are higher than the superior critical values reported in the studies presented. This confirms the existence of the cointegration between the analyzed variables in the case of the Eastern European countries. 
Results of Cointegration Test

\begin{tabular}{lccl}
\hline & p-value & ARDL (lag structure) & F statistic \\
\cline { 2 - 4 } Bulgaria & 0.3164 & $1,1,1$ & 8.27743 \\
Czech Republic & 0.2752 & $1,1,1$ & 22.3004 \\
Estonia & 0.4132 & $1,1,1$ & 7.6601 \\
Hungary & 0.5708 & $1,1,1$ & 16.1079 \\
Latvia & 0.2833 & $1,1,1$ & 13.2535 \\
Lithuania & 0.4160 & $1,1,1$ & 6.7913 \\
Poland & 0.4871 & $1,1,1$ & 20.2988 \\
Romania & 0.0223 & $1,1,1$ & 29.7790 \\
\hline
\end{tabular}

Note: Pesaran et al. (2001) Critical Values for ARDL Modeling Approach

For I(0) series: significance at $1 \%, 5 \%$ and $10 \%$ levels respectively 4.29, 3.23, 2.72

For I(1) series: significance at $1 \%, 5 \%$ and $10 \%$ levels respectively $5.61,4.35,3.77$

Source: own calculations

In table 5 we present the values of the estimated coefficients. The results show that the coefficients for some variables have the signs correctly forecasted by the theory. These results indicate that the coefficients corresponding to $\operatorname{Exp}, \operatorname{Exp}^{2}$ and $U$ from equation (3) are statistically significant at the $5 \%$ significance threshold.

Both coefficients for the government size, Exp and $E_{x p}{ }^{2}$, are statistically significant and have the signs in line with the literature proving the existence of the Armey Curve.

The estimated values of the coefficient of determination $\left(R^{2}\right)$ validate the models; this confirms the hypothesis of the $\cap$-type curve which describes the impact of the government size on the economic growth. The results state that the Armey Curve exists only in three Eastern-European countries as we can notice in Table 5, namely Bulgaria, Hungary and Romania. For the other analyzed countries, there is no Armey Curve because the coefficients corresponding to $\operatorname{Exp}^{2}$ are positive.
Estimated Long Run Coefficients using the ARDL Approach and Based on Schwarz Criterion

\begin{tabular}{|c|c|c|c|c|c|}
\hline \multirow{3}{*}{ Bulgaria } & $\alpha_{0}$ & $\alpha_{1}$ & $\boldsymbol{\alpha}_{2}$ & $\boldsymbol{\alpha}_{3}$ & $\mathbf{R}^{2}$ \\
\hline & 4.9802 & 0.3292 & -0.0043 & -0.4360 & 0.5405 \\
\hline & $(0.000)$ & $(0.001)$ & $(0.031)$ & $(0.008)$ & \\
\hline \multirow{4}{*}{$\begin{array}{l}\text { Czech } \\
\text { Republic } \\
\text { Estonia }\end{array}$} & 4.6070 & -2.6788 & 0.0268 & -4.4811 & 0.7052 \\
\hline & $(0.004)$ & $(0.001)$ & $(0.000)$ & $(0.0364)$ & \\
\hline & 45.8914 & -1.7298 & 0.02250 & -0.7318 & 0.3641 \\
\hline & $(0.0202)$ & $(0.0058)$ & $(0.0070)$ & $(0.0033)$ & \\
\hline \multirow[t]{2}{*}{ Hungary } & 91.2021 & 1.7152 & -0.0205 & -2.2254 & 0.4866 \\
\hline & $(0.0139)$ & $(0.0055)$ & $(0.0042)$ & $(0.0000)$ & \\
\hline \multirow[t]{2}{*}{ Latvia } & 35.3059 & -2.3076 & 0.0269 & -0.9364 & 0.4548 \\
\hline & $(0.0017)$ & $(0.0000)$ & $(0.0048)$ & $(0.0219)$ & \\
\hline \multirow[t]{2}{*}{ Lithuania } & 27.7141 & -0.8321 & 0.0114 & -1.3470 & 0.5262 \\
\hline & $(0.0004)$ & $(0.0097)$ & $(0.0033)$ & $(0.0159)$ & \\
\hline \multirow[t]{3}{*}{ Poland } & 433.549 & - & 0.2014 & -0.6509 & 0.7565 \\
\hline & $(0.0069)$ & 17.0484 & $(0.0007)$ & $(0.0000)$ & \\
\hline & & $(0.0041)$ & & & \\
\hline \multirow[t]{2}{*}{ Romania } & 18.4795 & 3.8128 & -0.0515 & -0.4360 & 0.6006 \\
\hline & $(0.0006)$ & $(0.0000)$ & $(0.0071)$ & $(0.0005)$ & \\
\hline
\end{tabular}

Note: $p$-value in bracket

Source: own calculations

The very large extent of state involvement in economy has led to a smaller economic growth while the moderate governmental size has triggered an increased growth. Using the equations considered before, the optimal size of the government which maximizes economic growth was determined to be of $38.23 \%$, for Bulgaria, $41.67 \%$ for Hungary and respectively $37.01 \%$ Romania.

In comparison with the present percentage of public spending from these countries, the governments spend at least $3 \%$ much more money than the amount needed to reach the optimization point. In other words, the government size is approximately $3 \%$ higher than the optimal value that favours growth $(3.4 \%$ in Bulgaria, 6.21 $\%$ in Hungary and $3.32 \%$ in Romania).

Our results have important implications for the assessment of the level of governmental spending and the elaboration of future financial and economic policies.

Table 6

Armey Curve test and Optimal Level of Expenditure

\begin{tabular}{lcc}
\hline & Is Armey Curve valid? & $\begin{array}{c}\text { Optimal Level of Expenditure (GDP \%) } \\
\text { Bulgaria }\end{array}$ \\
\cline { 2 - 3 } Czech Republic & Yes & 38.2378 \\
Estonia & No & \\
Hungary & No & \\
Latvia & Yes & 41.63 \\
Lithuania & No & 41.6796 \\
Poland & No & \\
Romania & No & 47.84 \\
\hline
\end{tabular}

Source: own calculations according to EUROSTAT

\section{Conclusions}

Using the ARDL model, we tested the presence of a non-linear Armey Curve-type relationship between the government size and economic growth in 8 EasternEuropean countries. The Armey Curve provides the opportunity to determine the optimal level of state involvement in economy and as a consequence, it can be used as an instrument of financial policy in the determination of optimal level of expenditure. Our results suggest that, in the case of Bulgaria, Hungary and Romania, the optimal percentage of governmental spending should be between $37 \%$ and $41.7 \%$

Therefore, when relating to the share of public sector in economy, it becomes obvious that the registered levels in 2013 are higher than the optimal level for these three 
countries. The exceedance of the optimal level may have the meaning that the size of public sector should be slightly decreased in these countries, since the public sector is not able to efficiently cope with its resources. These empirical observations may have significant effects on the planning of public expenditure and future expenditure policies.

\section{Acknowledgements}

This work was supported by a grant of the Romanian National Authority for Scientific Research and Innovation, CNCS UEFISCDI, project number PN-II-RU-TE-2014-4-0291.

\section{References}

Acemoglu, D. (2009). Introduction to Modern Economic Growth. Princeton, NJ: Princeton University Press.

Afonso, A., \& Furceri, D. (2010). Government Size, Composition, Volatility and Economic Growth. European Journal of Political Economy, 26(4), 517-532. https://doi.org/10.1016/j.ejpoleco.2010.02.002

Afonso, A., Schuknecht, L., \& Tanzi, V. (2010). Public Sector Efficiency: Evidence for New EU Member States and Emerging Markets. Applied Economics, 42(17), 2147-2164. https://doi.org/10.1080/00036840701765460

Agell, J., Lindh, T., \& Ohlsson, H. (1997). Growth and the Public Sector: A Critical Review Essay. European Journal of Political Economy, 13(1), 33-52. https://doi.org/10.1016/S0176-2680(96)00031-6

Aghion, P., \& Howitt, P. (2009). The Economics of Growth. Cambridge, MA: MIT Press.

Armey, D. (1995). The Freedom Revolution. Washington: Regnery Publishing.

Barro, R. J. (1991). Economic Growth in a Cross Section of Countries. The Quarterly Journal of Economics, 106 (2), 407-443. https://doi.org/10.2307/2937943

Barro, R. J. (1990). Government Spending in a Simple Model of Endogenous Growth. The Journal of Political Economy, 98 (5), 103-125. https://doi.org/10.1086/261726

Barro, R. J., \& Sala-i-Martin, X. (1992). Public Finance in Models of Economic Growth. Review of Economic Studies, 59(4), 645-661. https://doi.org/10.2307/2297991

Barro, R. J., \& Sala-i-Martin, X. (2004). Economic Growth, Second Edition. Cambridge, MA: MIT Press.

Chen, S., \& Lee, C. (2005). Government Size and Economic Growth in Taiwan: A Threshold Regression Approach, Journal of Policy Modeling, 27, 1051-1066. https://doi.org/10.1016/j.jpolmod.2005.06.006

Colombier, C. (2011). Does the Composition of public Expenditure Affect Economic Growth? Evidence from the Swiss Case. Applied Economics Letters, 18(16), 1583-1589. https://doi.org/10.1080/13504851.2011.554361

Dalamagas, B. (2000). Public Sector and Economic Growth: The Greek Experience Applied. Applied Economics, 32(3), 277-288. https://doi.org/10.1080/000368400322705

Dar, A., \& Amir Khalkhali, S. (2002). Government Size, Factor Accumulation and Economic Growth: Evidence from OECD Countries. Journal of Policy Modeling, 24 (7-8), 679-692. https://doi.org/10.1016/S0161-8938(02)00163-1

Deacon, B. (2000). Eastern European Welfare states: The Impact of the Politics of Globalization. Journal of European Social Policy, 10(2), 146-161. https://doi.org/10.1177/a012487

De Witte, K., \& Moesen, W. (2010). Sizing the Government. Public Choice, 145(1/2), 39-55. https://doi.org/10. 1007/s11127-009-9527-7

Facchini, F., \& Melki, M. (2013). Efficient Government Size: France in the 20th Century. European Journal of Political Economy, 31, 1-14. https://doi.org/10.1016/j.ejpoleco.2013.03.002

Feder, G. (1982). Exports and Economic Growth. Journal of Development Economics, 12, 59-73. https://doi.org/10.1016/0304-3878(83)90031-7

Folster, S., \& Henrekson, M. (2001). Growth Effects of Government Expenditure and Taxation in Rich Countries. European Economic Review, 45(8), 1501-1520. https://doi.org/10.1016/S0014-2921(00)00083-0

Forte, F., \& Magazzino, C. (2011). Optimal Size Government and Economic Growth in EU Countries. Economia politica, 28(3), 295-322.

Grossman, P. (1987). The Optimal Size of Government. Public Choice, 53, 131-147. https://doi.org/10.1007/BF 00125845

Gupta, S., Leruth, L., De Mello, L., \& Chakravarti, S. (2003). Transition Economies: How Appropriate is the Size and Scope of Government. Comparative Economic Studies, 45(4), 554-576. https://doi.org/10.1057/palgrave. ces.8100014

Hansson, P., \& Henrekson, M. (1994). A New Framework for Testing the Effect of Government Spending on Growth and Productivity. Public Choice, 81(3/4), 381-401. https://doi.org/10.1007/BF01053239 
Kalaitzidakis, P., \& Kalyvitis, S. (2005). "New" Public Investment and/or Public Capital Maintenance for Growth? The Canadian Experience. Economic Inquiry, 43(3), 586-600. https://doi.org/10.1093/ei/cbi040

Karras, G. (1996). The Optimal Government Size: Further International Evidence on the Productivity of Government Services. Economic inquiry, 34(2), 193-203. https://doi.org/10.1111/j.1465-7295.1996.tb01372.x

Kolluri, B. R., Panik, M. J., \& Wahab, M. S. (2000). Government Expenditure and Economic Growth: Evidence from G7 Countries. Applied Economics, 32(8), 1059-1068. https://doi.org/10.1080/000368400322110

Lin, S. A. (1994). Government Spending and Economic Growth. Applied Economics, 26(1), 83-94. https://doi.org/10. 1080/00036849400000064

Mencinger, J., \& Aristovnik, A. (2013). Fiscal Policy Stance in the European Union: The Impact of the Euro. Inzinerine Ekonomika-Engineering Economics, 24(1), 52-62. https://doi.org/10.5755/j01.ee.24.1.1614

Nijkamp, P., \& Poot, J. (2004). Meta-Analysis of the Effect of Fiscal Policies on Long-Run Growth. European Journal of Political Economy, 20(1), 91-124. https://doi.org/10.1016/j.ejpoleco.2003.10.001

Pesaran, M. H., Shin, Y., \& Smith R. J. (2001). Bound Testing Approaches to the Analysis of Long Run Relationships. Journal of Applied Econometrics, 16, 289-326. https://doi.org/10.1002/jae.616

Pevcin, P. (2004). Economic Output and the Optimal Size of Government. Economic and Business Review, 6(3), 213227.

Ram, R. (1986). Government Size and Economic Growth: A New Framework and Some Evidence from Cross-Section and Time-Series Data. The American Economic Review, 191-203.

Romero-Avila, D., \& Strauch, R. (2008). Public Finances and Long-term Growth in Europe: Evidence from a Panel Data Analysis. European Journal of Political Economy, 24(1), 172-191. https://doi.org/10.1016/j.ejpoleco.2007.06.008

Scully, G. W. (2003). Optimal Taxation, Economic Growth and Income Inequality. Public Choice, 115(3/4), 299-312. https://doi.org/10.1023/A:1024223916710

Shelton, C. A. (2007). The Size and Composition of Government Expenditure. Journal of Public Economics, 91(11), 2230-2260. https://doi.org/10.1016/j.jpubeco.2007.01.003

Sineviciene, L., \& Vasiliauskaite, A. (2012). Fiscal Policy Interaction with Private Investment: the Case of the Baltic States. Inzinerine Ekonomika-Engineering Economics, 23(3), 233-241. https://doi.org/10.5755/j01.ee.23.3.1934

Solow, R. M. (1956). A Contribution to the Theory of Economic Growth. Quarterly Journal of Economics, 70(1), 65-94. https://doi.org/10.2307/1884513

Zivot, E., \& Andrews, D. W. K. (1992). Further Evidence on the Great Crash, the Oil-price Shock and the Unit-root Hypothesis. Journal of Business \& Economic Statistics, 10, 251-270. https://doi.org/10.1080/07350015.199 2.10509904

Vedder, R., \& Gallaway, L. (1998). Government Size and Economic Growth. Joint Economic Committee, Washington D.C., 1-15.

The article has been reviewed.

Received in August, 2014; accepted in April, 2017. 